\title{
A comparison of the performance of a compomer and an amalgam
}

Clinical performance of a compomer and amalgam for the interproximal restoration of primary molars: a 24-month evaluation. M. S. Duggal, K. J. Toumba and N. K. Sharma Br Dent J 2002; 193: 339-342

\section{Objectives}

To evaluate the clinical performance of a compomer material (Dyract $\left.{ }^{\circledR}\right)$ in comparison with dental amalgam (Contour ${ }^{\circledR}$ ) for management of proximal caries in primary molars in young children.

\section{Setting}

General dental practice, and a dental hospital paediatric clinic.

\section{Method}

This was a prospective study. A split mouth design was used with identical pairs of minimal Class II cavities, of matched tooth type in the same dental arch, usually diagnosed with the use of bitewing radiographs. Seventy-eight pairs of restorations were completed of which 60 pairs were available for evaluation after 24 months.

\section{Results}

Comparable retention rates were observed for both Dyract and amalgam. The retention rates were high for both materials, with only four amalgam and two Dyract restorations failing over 24 months. Significantly better marginal integrity $(p<0.05)$ was observed for Dyract compared with amalgam with no significant differences between the two materials for recurrent caries, wear or surface texture.

\section{Conclusions}

Dyract seemed to be a suitable alternative to amalgam for proximal restorations in primary molars of young children for use in general dental practice.

\section{IN BRIEF}

1 There is a need to study suitable alternatives to amalgam for use in primary teeth.

1 This was a comparative study to evaluate the performance of Dyract and amalgam for restoration of minimal proximal caries removed after administration of local analgesia in primary teeth.

1 Evaluation of restorations for recurrent caries, wear, marginal integrity and surface texture showed that Dyract performed slightly better than amalgam, though significantly only for marginal integrity.

1 Dyract is a suitable alternative to amalgam both in general dental practice and a specialist environment when used for restoration of minimal proximal caries.

\section{COMMENT}

Clinicians are always faced with the question of what is the best material to use in restoring carious teeth. Amalgam has been used extensively in restoring primary molars but because of its aesthetics and the public fear of mercury toxicity, alternative tooth colour restorative materials have been tried with variable success rates. This paper conducted a prospective study comparing the success rates between amalgam and compomer (Dyract) in restoring the proximal lesions of primary molars. The two years' results showed that both materials had high retention rates with more that $90 \%$ of the restorations remaining functional. However, more than $10 \%$ of the restorations had recurrent caries and one wonders whether some of the 'functional' restorations should be replaced. Dyract was shown to have significantly better marginal integrity than amalgam and, surprisingly, slightly better wear resistance as well.

This is a well designed prospective study with split mouth design to reduce the patient bias. However, it suffers from the inevitable problem of number of subjects and failure of follow up (18 out of 78 patients were unavailable at 24 months). There is a recent controversy on whether it is worthwhile restoring primary teeth in general practice because of its high failure rate. This paper shows that if a clinician respects the material and follows the standard cavity design, a high success rate can be achieved in general dental practice despite the choice of material. Compared with a retrospective study carried out in a general dental practice, ${ }^{1}$ the use of bitewing radiographs to diagnose proximal caries is a major factor in enhancing the success rate of a restoration. If the lesion is extensive, it has been shown by many studies that stainless crowns should be the choice of restoration.

\section{F. S. L. Wong, Senior Lecturer/Honorary Consultant,} Paediatric Dentistry, Barts and The London, Dental Hospital

1. Wong FS L, Day S J. An investigation of factors influencing the longevity of restorations in primary molars. J Int Ass Dent Child 1990; 20: 11-16. 